\title{
Child Labor and Reproduction of Family Poverty in Puno: A Pending Social Debt
}

\author{
Juan Inquilla Mamani \\ National University of the Altiplano, Puno, Peru \\ Email: inquilla@hotmail.com
}

How to cite this paper: Mamani, J.I. (2018) Child Labor and Reproduction of Family Poverty in Puno: A Pending Social Debt. Open Access Library Journal, 5: e4473.

https://doi.org/10.4236/oalib.1104473

Received: March 6, 2018

Accepted: April 24, 2018

Published: April 28, 2018

Copyright (๐ 2018 by author and Open Access Library Inc.

This work is licensed under the Creative Commons Attribution International License (CC BY 4.0).

http://creativecommons.org/licenses/by/4.0/

(c) (i) Open Access

\begin{abstract}
Child labor violates the rights of children enshrined in the Convention on the Rights of the Child (CRC) of the United Nations (UN), but also reproduces poverty in our country. In Peru, this type of work is not a novelty, but historical studies reveal that until the 1990s it was viewed with indifference by governments and other instances of society. The present research "Child labor and poverty in Puno", has as objective: Determine the association between child labor and reproduction of family poverty in Puno. The study areas have been selected, taking into account the places with the highest concentration of children who carry out economic activities with their parents: The area of Salcedo "the brickworks in the Rinconada", Jr. Los Incas and the surroundings of the stadium "ETB", the Bellavista market and Mercado Union and Dignidad, as well as some parks and main streets where they carry out their economic activities informally. The Study Method is inductive of correlational-longitudinal design. Sample: The universe of the population under study is made up of adults who were formerly street children and adolescents in the city of Puno. Results: Child labor interferes in many ways: First, it decapitalizes in two to three years of study approximately with respect to those that do not work; second, the effort that work demands them has a negative impact on school continuity in the future. When not reaching the expected level in education, the possibility of repetition increases, which in turn generates delay and facilitates the desertion and consequently by the constant repetitions and desertions makes possible the definitive abandonment of the school. Therefore, child labor in the current conditions is twice the fundamental rights of children, places conditions of informality when they are adults and reproduces family poverty in our country in a generational manner.
\end{abstract}

\section{Subject Areas}

Education, Sociology 


\section{Keywords}

Child Labor, Reproduction of Family Poverty, Child Rights, Education and Health

\section{Introduction}

The research focuses on the explanation of the association between child labor and the reproduction of family poverty in Puno. In the work process we try to demonstrate the levels of association between child labor and reproduction of poverty explained in the educational variables, family income level and level of employment in adulthood. Considering that the object of study is based on the longitudinal analysis of the facts, given that the population under study are adults were child laborers in their childhood. The research was carried out in the areas with the highest concentration of working street children, an indicator that facilitated access to obtaining data with adults who are currently parents. The selected places have been: The area of Salcedo "the brickworks in the Rinconada", Jr. Los Incas and surroundings of the stadium "ETB”, the Bellavista market, and the market, Union Market - Dignity and some parks, main streets where people perform out their economic activities informally. Another factor that has allowed us access to objective and real information is the work experience we have developed with these families through a National INABIF Program (Street Educators Program); without this opportunity it would not have been possible to have the information contained in this work.

The available information allows us to sustain that child labor with the characteristics of survival in which it is practiced today is directly associated with the reproduction of family poverty in Puno [1]. This statement is based on the statistical tests that were carried out throughout the work. The central variables that have allowed us to demonstrate this association have been the following: Child labor as an independent and influential variable, its indicators have been, forms of work, hours of work, working conditions and types of work (before and after); then we defined some intermediate variables such as education with its indicators of school repetition, school dropout and school dropout, for each one the measurement indices were elaborated; income level with its indicators of high, medium and low, with similar methodology has been developed the indices for each indicator; the variable level of employment reached in adulthood, for this variable was established indicators such as type of employment in adulthood, forms of employment, hours of work in adulthood; and finally, we associate with the level of family poverty as a dependent variable, and our indicators have been: Income level, housing conditions, basic services, health and food conditions.

On the other hand, there are studies of [2] who make their contribution by finding factors such as the age of majority, being male and poverty; These are related to children and adolescents leaving school to dedicate themselves solely 
to work or in some cases to work and study. Likewise, the author shows that better educational levels of the mother have an inverse relationship with the probability that the child works. In the same perspective, we have the studies of [3] [4] assure that the lack of resources means that some families in poverty are forced to give priority to increase income at the expense of the education of their children; that is to say, families that are structurally poor and have the problem that child labor is reproduced generationally, observe a vicious circle in which children must help the family, particularly their younger siblings and their old parents advanced, that are limited to develop certain activities. [5] concludes that, although there is a legal framework regarding child labor, this evil will follow its path in a vicious circle, with few tendencies to get out of it. What will ensure the decrease of child labor will be, a qualification of the parents; the country reaches levels of development and decreases school drop-out so that children with the accumulation of skills can make the social leap and break this vicious circle.

\section{Theoretical Framework}

Theoretical reflections focus on the question: what to do with the children of the poor?, is basically the starting point for any approach, in the contemporary debate there are three major positions on the work of children and adolescents in Latin America, [6] [7] [8]. The elimination of child labor as a final goal purpose that originally has hoisted the International Labor Organization (ILO), since 1919. This agency, is opposed to all forms of work in which the child is exploited, takes advantage of their weakness, he is exposed to risks, he is prevented from being educated and trained. In this regard we find statements such as the Director General of the ILO [9] [10], children who are prematurely living as adults, working many hours a day for low wages and in conditions that are detrimental to their health and for their physical and mental development, sometimes away from their families, often deprived of any significant opportunity for education and training capable of procuring a better future for them. At the Latin American level, an important role in this issue has been developed by Emilio García Méndez, regional advisor of UNICEF, always within the framework of a general policy of elimination of child labor, this author introduces at least two central contributions: the methodological and pragmatic side of action [11] [12].

The vindication of work as the right of childhood. If in the analysis and proposal of the first approach that focuses basically on harmful child and youth work, this perspective places as an axis of concern all activity that children and adolescents undertake tending to the production and reproduction of their living conditions, be they These activities are legal or illegal, harmful or benign without any difference [13] [14] [15] and only on this basis is it possible to base, strengthen their organizational perspective, justify their ambition to become a social movement and potentially political to respond to what we do to transform a sys- 
tem that only makes the rich richer and more miserable to the already poor?, paradigm that has articulated the experience of Manthoc in our country and the movement of NATs in Nicaragua, in Bolivia, in Mexico, in Argentina [14]. The short vision placist, in this last approach there is no explicit definition in the final objectives of the intervention. The intervention is focused on the short term [16]. The urgency is addressed, the concern is to improve the living conditions of working children in areas such as health, education, self-esteem, among others [17].

According to the studies [18] [19] they point out that children work simply because they have to do it, that is, because their family needs their economic contribution to maintain a minimum level of subsistence. The poorest families, in the effort to reproduce, opt for the mobilization of all possible resources, including children who can be summoned for the exercise of tasks, paid or not, which concern both the production and the social reproduction. According to [20] finds up to four main approaches, two of which are rights and capabilities and social exclusion [21]. They also consider two other approaches that do not seem to be comparable approaches to the two mentioned or those we propose. These are the so-called monetary and participatory approaches [22]. The first is descriptive, focusing on the operational definition of poverty and the measurement of monetary poverty, that is, of quantifying the part of the population (or families) that obtains income in money below a norm (or line) of income that is taken as reference [23]. The second, participatory, is only a method of knowing or approaching poverty and not a proper approach. In this regard [24] mentions, the quality of life depends on a series of services such as child nutrition, consumption of health services, housing with drinking water and sewerage and basic education.

Today the increase in child labor and school dropout, the growing and palpable gap between the included and the excluded gives the disturbing feeling that the poor no longer exist there and that in some way we are all involved in the multiplication of poverty, which he refuses to decrease. The research carried out by [25], indicates that the lack of basic education prevents access to even the lowest sectors of the formal labor market, decisively contributing not only to the consolidation and reproduction of the cycle of poverty but also of the marginality cycle; On the other hand [26] [27], point out that investment in children's education and health is a central piece in breaking the cycle of poverty and aspiring to human development with equity.

The relationship between work and education is reciprocal. Many children and adolescents work to study, while others do not study for work, however, help their parents or not in the payment of school and purchase of supplies, the result is the same, due to long days Work and the excess physical effort that most occupations involve, children arrive at school tired, with difficulty concentrating while others are absent from the classroom. [17]. In the long term, working children and adolescents due to the loss of education, which such activity im- 
plies, being adults, could only access the occupations that require less qualification and therefore will be the lowest paid [16] [6]. The majority of the poor and extremely poor population has a job, but it lacks employment. In this regard [28], he mentions that those excluded from the labor market will become the poorest in society, explaining the relationship between exclusion from the labor market and the type of employment of people.

\section{Methodology}

The study is based on determining the level association between "child labor and the reproduction of poverty". At this level the study is quantitative correlational design-fore and aft. Priority was given to the dimensions social, educational, employment and income. Taking as the unit of observation to adults who as children have been street workers. The universe of the study sample is made up of adult persons who before were girls and child workers in the city of Puno (Table 1).

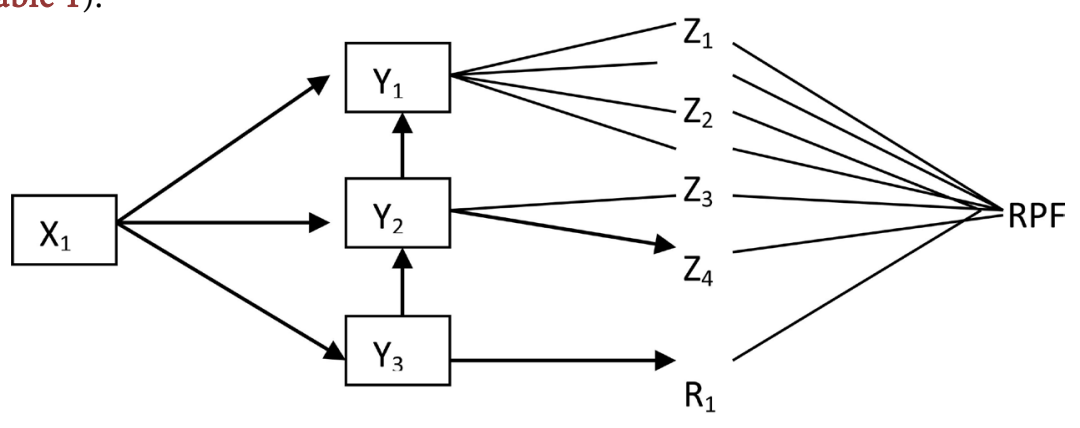

The study areas include the following:

Zona Ladrillera de Salcedo. This area is mainly characterized by developing activities or manufacturing bricks in a traditional way. Entire families are dedicated to making bricks for sale. Their income is mainly supported by the sale of

Table 1. Simple random sample.

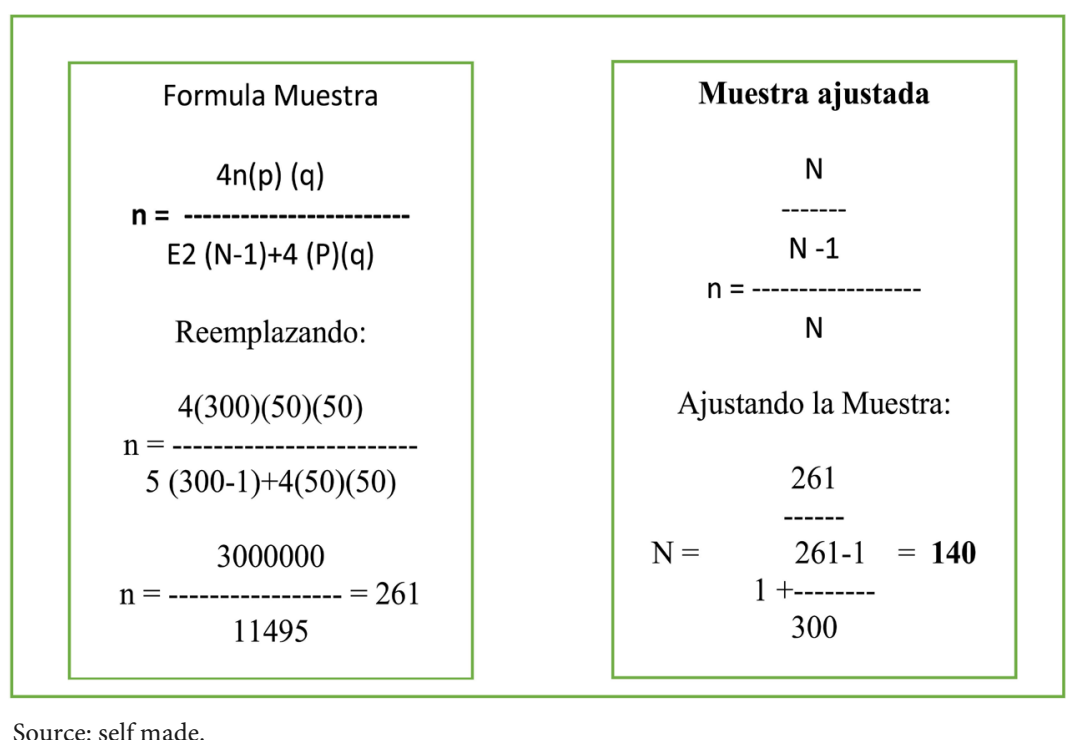


bricks. They usually work as day laborers for owners of furnaces or dealerships.

Zona Cercado Jr. The Incas and around the Torres Belón Stadium, Bellavista Market, Laykakota, Unión y Dignidad. These are families dedicated primarily to the activity of informal commerce. Therefore, their income comes from the commercial exchange of products from the area (potatoes, chuño, vegetables, cereals, groceries in smaller amounts).

Ramón Castilla Park Area. These are people dedicated as construction helpers. They are characterized by the sale of their daily work force for a wage. Your income depends on the type of activity you perform on the day.

Zone Cercado de la ciudad. It includes the population that is dedicated to the activities of services such as: tricyclists, motorcycle taxi drivers, package loaders, shoe polishers, etc. They are characterized by the way they work. Your income depends on the amount of services you perform during the day. Another group of people are located in more formal activities such as mechanics workshops, bus drivers, etc.

\section{Results and Discussions}

\subsection{Child Labor and Education: Effects in the Short, Medium and Long Term}

When the occupation rate presents a direct relationship with the age of the children; thus, for children of 5 years, the rate rises to 1.7 percent while, at the other extreme, 42.3 percent of 17 -year-olds do some economic activity. It shows that, on average, children begin to perform economic activities on average at 9 years of age, that is, 3 years below the legally permitted age according to the Peruvian Legislation. Rural children start working, on average, 3 years before the children who live in the urban area; Girls are incorporated into economic activities, on average, one year before boys. It is possible that the type of parental attachment to the labor market (economic sector, relationship of labor dependence, distance between home and work center, etc.), the customs and values of the family in relation to the work of children and the level of family well-being can be important elements to explain the age at which children enter the labor market [29]. The number of working children and adolescents is differentiated by area of residence and by departments, depending on the demographic and social variables that characterize these areas and departments. The largest number of employed persons between the ages of 6 and 17 is in the departments of Lima, Cajamarca, Puno, Cusco, Ancash and Piura, which together house about 2 million working children and adolescents; that is to say, they represent $58.1 \%$ of the total of employed persons of that age group.

Seen from the whole of a society, a better educational level of the population results in greater opportunities for growth and well-being for all. Hence, there is a growing consensus in considering education as an investment and not as an expense [6]. In the case of children in poverty, formal education favors equal 
opportunities and widens the possibilities of social inclusion (Graph 1).

Child labor interferes with this process in multiple ways: In the analysis presented below, the level of association between the variables of child labor and school repetition is demonstrated. The analysis is made to measure the degree of association that exists between the two variables mentioned above, in order to identify the correlation that it holds between these variables. Graph 1 shows that there is a high and direct correlation between child labor and school repetition, which means "the higher the level of child labor, the higher the level of school repetition", that is, a coefficient of correlation of 0.86 . Consequently, the more time children dedicate to work, the greater the probability of repeating school years in Puno (Graph 2).

Another indicator that can be observed, for purposes of analyzing, how much it affects child labor in education is school dropout. The emperial evidence observed in Graph 2, fits the linear trend, and points are not scattered from the line, so it is confirmed that the association is high between the two variables analyzed. The results show us that the data are more adjusted to the straight line,

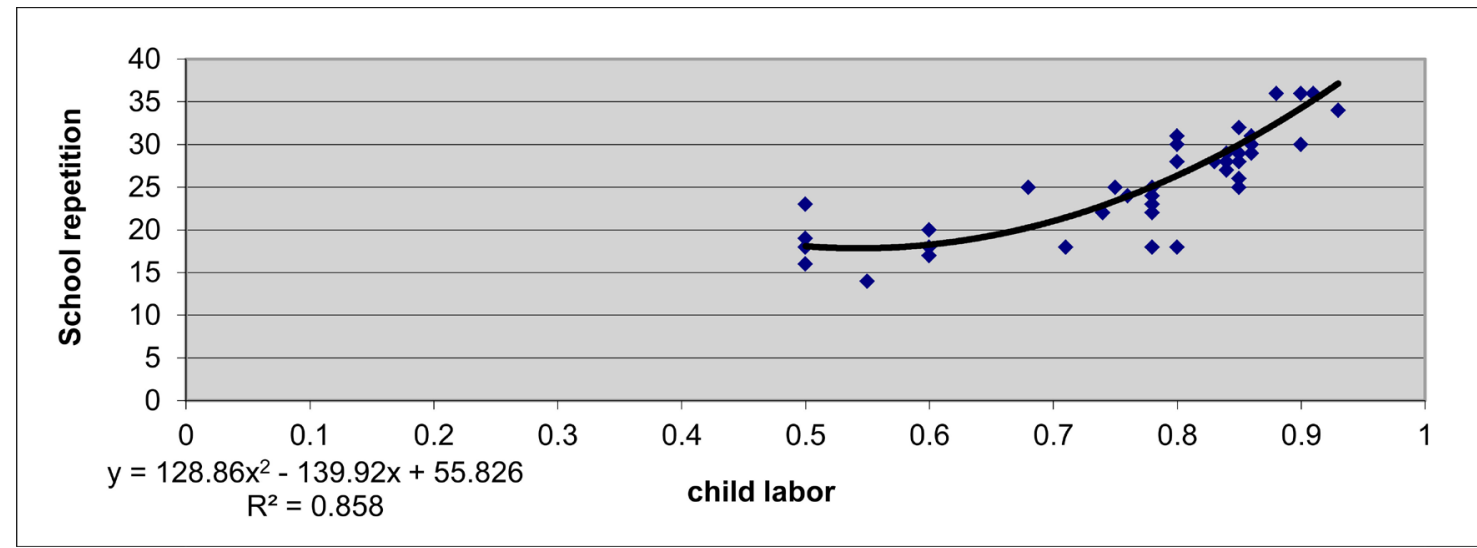

Source: Own elaboration based on data from the survey conducted, 2016.

Graph 1. Association between child labor and school repetition.

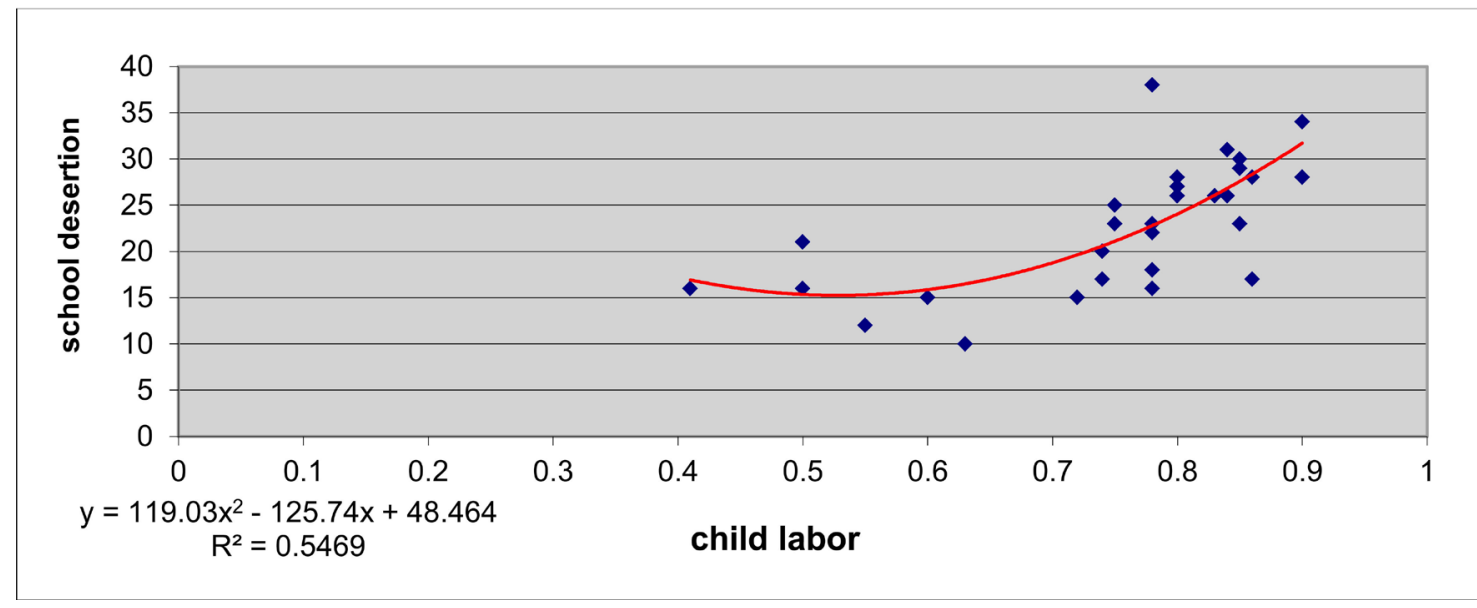

Source: Own elaboration based on data from the survey conducted, 2016.

Graph 2. Association between child labor and school dropout. 
so the dispersion of the data are points that confirm the above, that there is a strong or high relationship between child labor and school dropout. On the other hand, the Coefficient of determination is 55\%, which indicates that child labor determines up to $55 \%$ of school dropouts in Puno.

We had argued in the previous pages that child labor causes notable losses at the level of education, losses that are directly associated with the time spent working in childhood and the conditions in which they perform their economic activities. Child labor causes immediate problems of school performance which leads to constant repetitions that eventually end up leaving school. Education is one of the fundamental human rights recognized and guaranteed by various national and international legal instruments. At the individual level it is the vehicle that allows social insertion and constitutes the key to access other rights such as health, nutrition, recreation, social participation, among others. In light of the empirical evidence, we can argue that children who work from an early age and attend school are decapitalized in two to three years of study approximately with respect to those who do not work. The effort that work demands them has a negative impact on performance and on the regularity of assistance. By not reaching the expected level, the chances of repetition increase, which in turn leads to school dropout and dropping out. Once they leave school, reintegration is more difficult than staying in the educational system (Graph 3).

In Graph 3, it is observed that there is a correlation of 0.75 , which is considered as high and direct, indicating that child labor is the variable that explains school dropout. The more time they dedicate to work, the greater the probability of dropping out of school. In the analysis of child labor, much importance has been given to long-term effects, a position that we endorse with the empirical evidence presented above. The loss of time dedicated to education also implies a loss of remuneration in future benefits. In fact, the investment in education in time $\mathrm{x}$ positively influences the stock of human capital. Such influence is

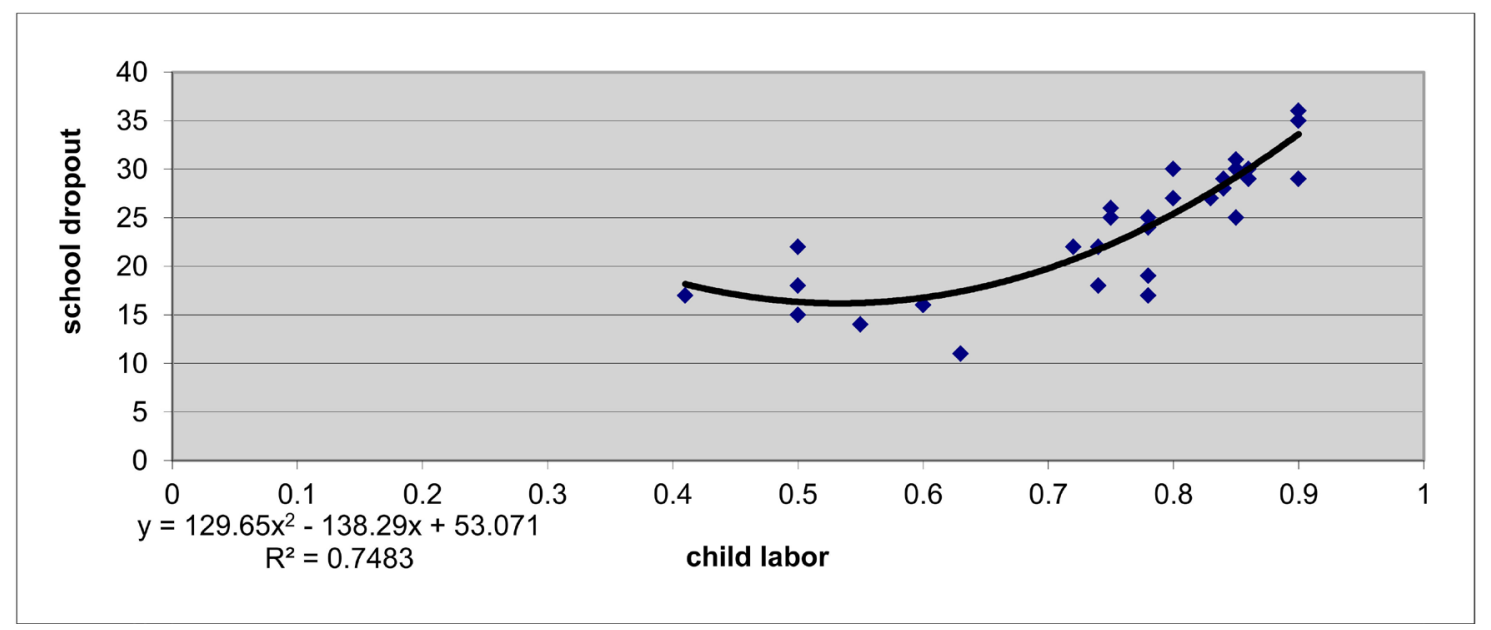

Source: Own elaboration based on data from the survey conducted, 2016.

Graph 3. Association between child labor and school abandonment. 
represented by the function, where the increase of the human capital benefits for a quality work and in better conditions during the whole future life period [30].

Then the reasons are obvious; The first is that the future returns on investments in human capital (health and education) are very low and therefore it is in the family's interest to have the child start working as soon as possible. The second is related to the fact that work from an early age, accumulates higher levels of experience, a fact that increases job performance and then also future salaries and in this way education is not only a consumer good, but also It deals with an investment good because it collaborates with the creation of future income by providing the individual with skills and abilities that allow him to obtain higher wages [31] [32] [33]. In effect, the acquisition of skills and knowledge is a form of capital (called human capital) and is the result of a deliberate investment decision. The implications of child labor in social development are explained by the effects it generates on human capital

\subsection{Analysis of the Association between Child Labor and Future Occupations of the Study Population}

When correlating child labor in the past with the level of employment in the present, that is, when they are already adults, we obtain a correlation coefficient of 0.79 , indicating a moderate and direct correlation; that is, there is a relatively strong association between these two variables. As a result, people who from an early age began to work and devoted more time to it, in the present have shortcomings and inadequate living conditions, therefore not adequately meet their basic needs, much less those strategic needs such as education and health. In the city of Puno, the socio-labor characteristics of the families included in the study are generally dedicated to informal economic activities: as outpatient trade, handicraft bricks, tricycles and moto-taxis, etc. (Graph 4).

There is no doubt that the effects of long-term child labor perpetuate poverty, condemning the inadequate living conditions, to the people who in their childhood were working children. Therefore, in our conclusion we can affirm that the higher the rate of child labor in the past, the greater the probability of accessing lower-skilled occupations. And the coefficient squared (r2) is equal to 0.69, which explains that child labor influences the current level of employment to 69\% (Graph 5).

In this regard the results show us that the data are adjusted very close to the trend line and there is no or very little dispersion of the data, this corresponds to the people who have achieved a higher educational level and therefore have been able to access to occupations in adequate conditions [31] [30]. The correlation observed is adverse and strong, since the graph shows us that the higher the rate of child labor in the (past), the lower the chances of accessing occupations of higher qualification and are occupied in survival activities in conditions inadequate and low income. When the effects of long-term child labor are observed in the present reverse working conditions, when condemning the inadequate 


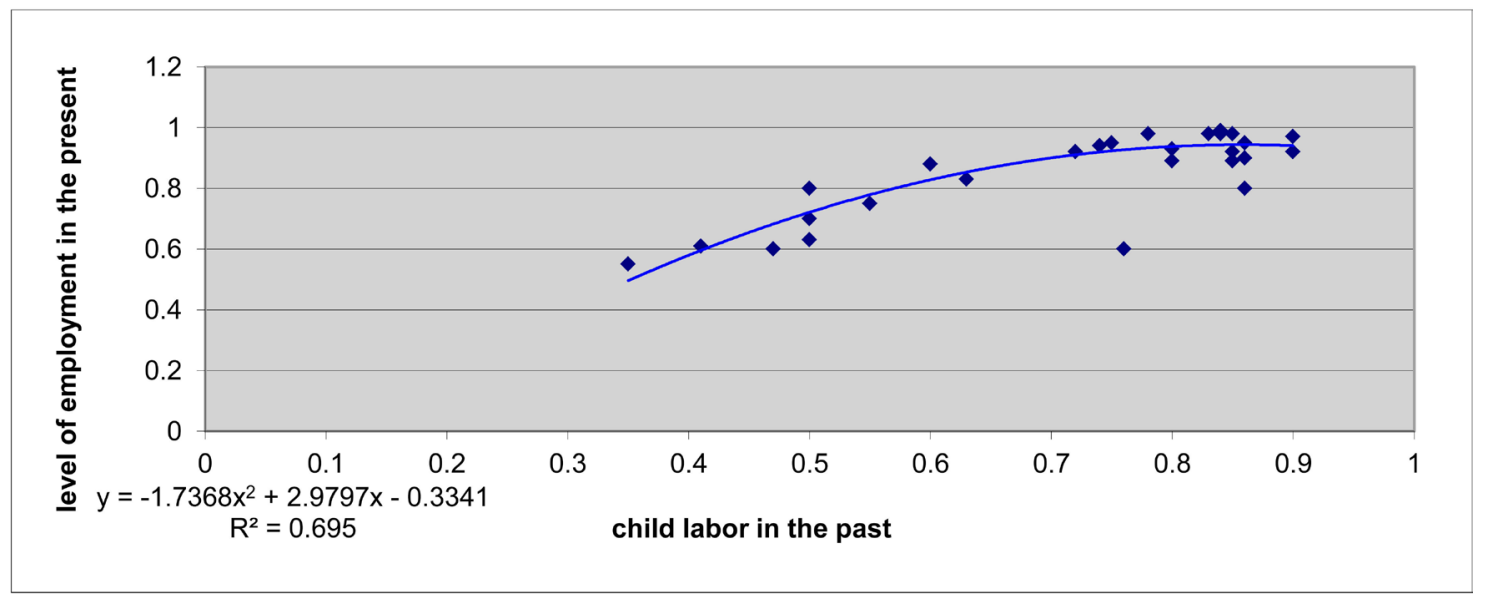

Source: Own elaboration based on data from the survey conducted, 2016.

Graph 4. Association between child labor (past) and level of employment achieved in (present).

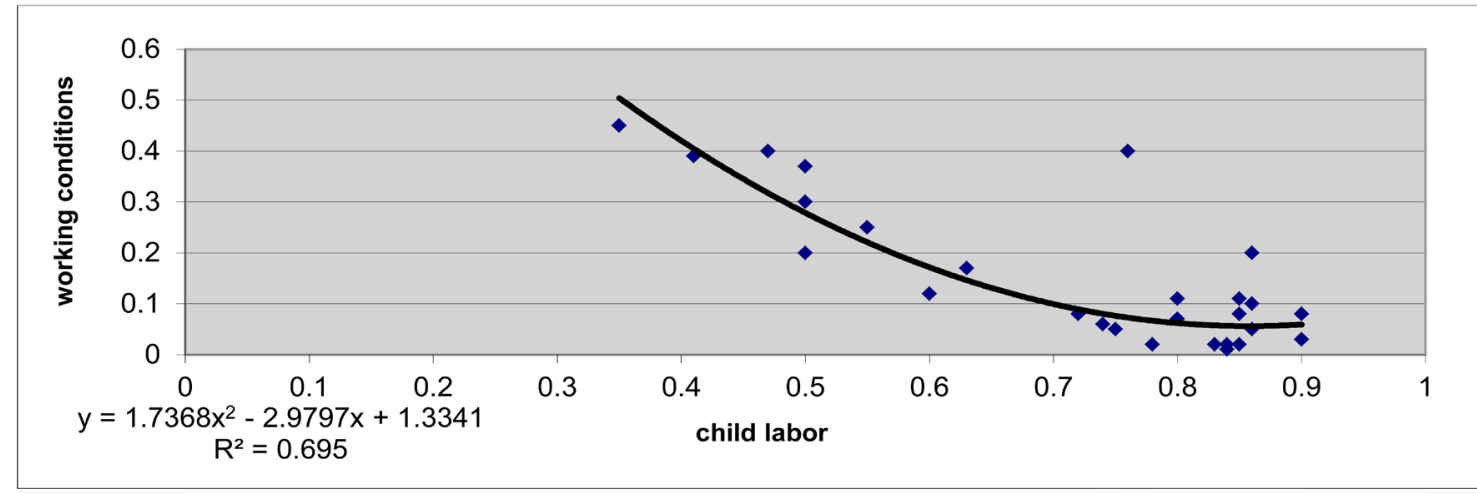

Source: Own elaboration based on data from the survey conducted, 2016.

Graph 5. Association between child labor (past) and working conditions of (present).

working conditions in the future to the people who in their childhood were working children. Therefore, in our conclusion we can affirm that the higher the rate of child labor in the past, the lower the probability of accessing occupations with higher qualifications. And the coefficient squared (r2) is equal to 0.69, which explains that child labor influences the conditions of future employment to $69 \%$ in Puno.

\subsection{Child Labor and Reproduction of Family Poverty}

The indicators considered for the process of our analysis are: for the variable "child labor" the indicators have been considered as; form of work, working conditions, hours of work, dedication to work. While the variable the "level of living conditions" will be represented by the indicators such as: housing conditions, health conditions, feeding conditions. Graph 6, shows the association between child labor and living conditions of the population in adulthood, once the measurement indices for each indicator are constructed, the following results are obtained. At the Pearson correlation coefficient, -0.76 was obtained, which means that the higher the rate of child labor in the past, the lower the probability 
of accessing adequate living conditions in the present. On the other hand, a coefficient of determination 0.62 was obtained, that is to say, the degree of determination of child labor in the past, on the living conditions in the present represents $62 \%$, which in our opinion is a quite significant percentage, which would be confirming our third specific hypothesis (Graph 6).

It was identified in the previous tables that the correlations between the variables represent values of high association. What explains the following chain of association: Premature child labor is directly associated with low levels of schooling, therefore, people in adulthood can not access higher-skilled occupations (low levels of employment), as a result they obtain low levels of income, consequently family poverty is reproduced. (Table 2) This is the vicious and adverse circle that generates child labor in our society and in particular in Puno. Analysis of the association chain $\mathrm{TI}=(\mathrm{NE}+\mathrm{NEP}+\mathrm{NIP}=\mathrm{RPF})$.

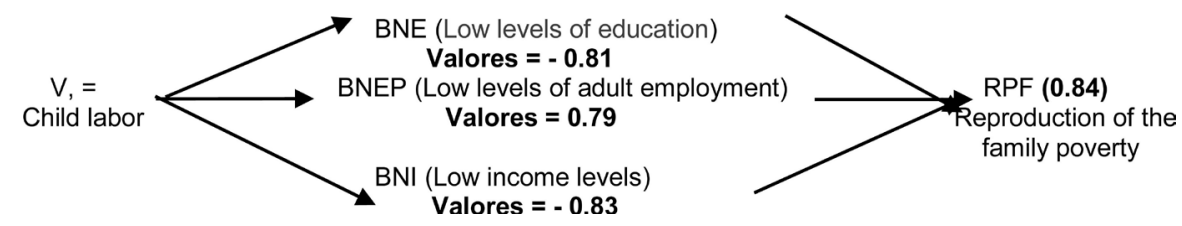

It is important to observe the chain of association at the level of values that represent the data. The variables in the first column represent positive values

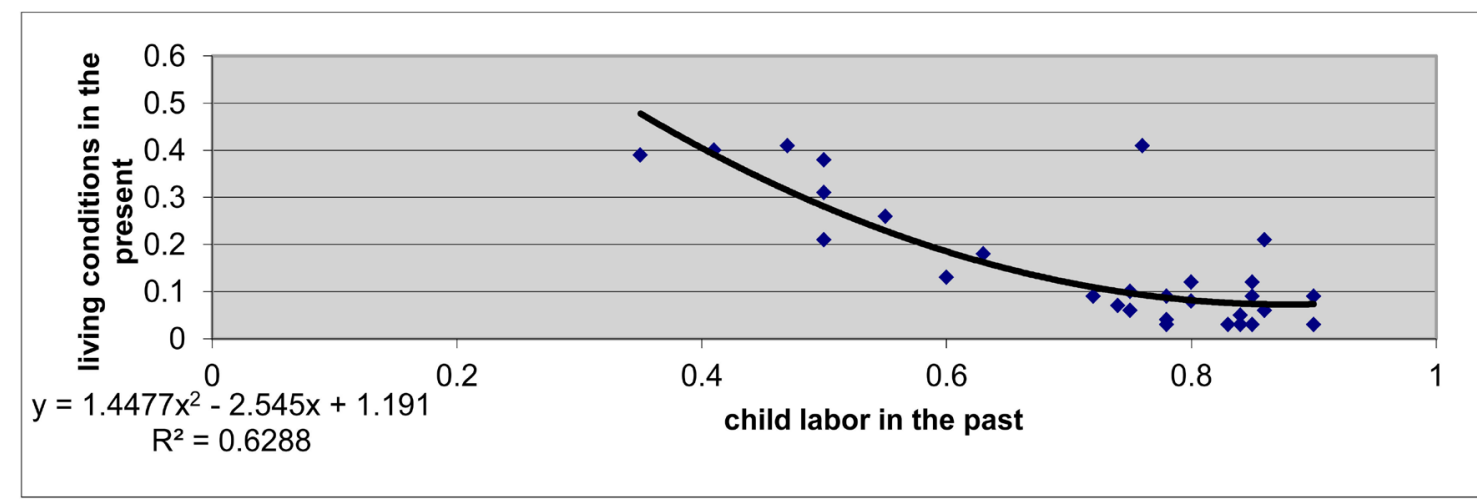

Source: Own elaboration based on data from the survey conducted, 2016.

Graph 6. Association between child labor (past) and living conditions (present).

Table 2. Values of the variable association chain.

\begin{tabular}{|c|c|c|c|c|c|}
\hline $\mathrm{X}$ & Child labor & Education level & $\begin{array}{c}\text { Level of } \\
\text { employment }\end{array}$ & Level of income & $\begin{array}{l}\text { Living conditions } \\
\text { (Poverty) }\end{array}$ \\
\hline Child labor & 1 & -0.81 & 0.79 & -0.83 & -0.76 \\
\hline Education level & Inversely associated & 1 & 0.76 & 0.73 & 0.77 \\
\hline Level of employment & $\begin{array}{l}\text { Directly associated with } \\
\text { low levels of employment }\end{array}$ & Directly associated & 1 & 0.82 & 0.86 \\
\hline Level of income & Inversely associated & Directly associated & Directly associated & 1 & 0.84 \\
\hline Living conditions & Inversely associated & Directly associated & Directly associated & Directly associated & 1 \\
\hline
\end{tabular}

Source: Own elaboration based on data from the survey conducted, 2016. 
and the variables in the first row represent negative values. That is, " $\mathrm{A}<\mathrm{X}<\mathrm{Y}$ " or vice versa " $\mathrm{A}<\mathrm{XY}$ ".

In this way, it can be observed that child labor is inversely associated with low educational levels, that is to say, the highest rate of child labor, lower level of education attained". On the other hand, child labor is directly associated to the low levels of employment adult, "A higher rate of child labor, the greater the likelihood of access to less skilled occupations in adulthood". In addition, child labor is inversely associated with low levels of income, "A higher rate of child labor income in adulthood". Finally, child labor is directly associated with the reproduction of family poverty in Puno. "A higher rate of child labor, the greater the probability of reproduction and consolidation of family poverty in the future."

\section{Conclusions}

In the case of children and adolescents living in poverty, formal education favors equal opportunities and widens the possibilities of social inclusion. However, child labor interferes with this process in many ways: On the one hand, it decapitalizes childhood, with respect to those who do not work; on the other hand, the effort demanded by work has a negative impact on school continuity. By not reaching the expected level, the possibility of repetition increases, which in turn generates delay and facilitates the desertion and consequently the definitive abandonment of the school. In light of the results obtained with the research, we can affirm that child labor is associated with low educational levels of people. That is to say, the higher the rate of child labor, the greater will be the educational problems expressed in: Repetition, dropping out and dropping out of school.

In the medium term, child labor interferes in school, limits possibilities for adequate employment in the future. That is to say, because of the loss in education that child labor implies, being adults have only been able to access the occupations with the lowest qualifications and, therefore, the lowest paid. The empirical results obtained in the research allow us to argue that child labor is associated negatively or adversely with the level of future employment. What it means, "the higher the rate of child labor, the less chance of accessing occupations with higher qualifications in the future". This situation leads people to be employed in survival occupations with low income levels.

In the long term, child labor becomes a factor of reproduction of family poverty in Puno; the evidence found allows affirming that the population used to work at an early age (boys and girls), now they are adults, but they remain poor, so the children who work today will be the parents of the new working children tomorrow and they will continue to be poor. The perverse circle of child labor, is explained in the following chain of association: Before, they were working children, in the process they left school, and as a result they are currently engaged in informal activities of lower qualification and with low remunerations therefore 
they are still in poverty. The same circle is reproduced, with their children who are working children today, who in the process will have serious educational problems (repetition, dropping out and school dropouts); therefore, tomorrow they will only be able to access occupations of lower qualification and with low income, consequently family poverty will reproduce.

\section{References}

[1] Inquilla, J. (2006) Tesis. Trabajo infantil y reproducción de la pobreza familiar en Puno. EPG-UNA-Puno.

[2] Avella, A.C.P. and Medina, R.R. (2006) El trabajo infantil y juvenil en Colombia y algunas de sus consecuencias claves. Revista Latinoamericana de Ciencias Sociales, Niñez y Juventud, 4, 1-28.

http://www.scielo.org.co/scielo.php?script=sci_arttext\&pid=S1692-715X2006000100 $\underline{008}$

[3] Díaz, M. and Rodríguez I. (1998) El trabajo infantil en el mundo: El estado de la discusión. Cuadernos de Estudios Empresariales, No. 8, 243-250.

[4] Fernandez, J. and De los Campos, H. (2005) Estudio de las características de los niños, niñas y adolescentes trabajadores y sus familias: modalidades de trabajo infantil y peores formas, perfil socioeconómico y cultural de las familias. AECI, IPEC (OIT), CETI, INFAMILIA, CIESU.

[5] Orozco, E. (2011) Estado del arte trabajo infantil. Civilizar, 12, 159-168.

[6] Alarcón, W. (1999a) Enfoques de políticas en torno al trabajo de niños y adolescentes en América Latina. en. Realidad y Utopía $\mathrm{N}^{\circ} 1$ Lima.

[7] Alarcón, W. and Salazar, M. (1996) Mejores Escuelas Menos Trabajo Infantil. Trabajo Infanto-Juvenil y educación en Brasil, Colombia, Guatemala, Ecuador y Perú. TACRO ONOCCENTI. Bogotá.

[8] Barreto, L. (1999) Vida al Borde de la Vida. Razones para la erradicación del trabajo nocivo de niñas, niños y adolescentes en los basurales. Proceso Social/ASE. Lima.

[9] Blanchard, F. (1983) El trabajo infantil: Manual de información. OIT. Ginebra.

[10] UNICEF (1998) El Trueque Virtuoso: La educación por trabajo infantil. Un cambio seguro hacia la construcción de la ciudadanía de la infancia. San José.

[11] García, E. and Araldsen, H. (1995) El debate actual sobre el trabajo infanto-juvenil en América Latina y el Caribe: tendencias y perspectivas. En Apuntes $\mathrm{N}^{\circ}$ 5. Lima.

[12] García, E. (1997) Trabajo Infantil y democracia en América Latina. En realidad y Utopía $\mathrm{N}^{\circ}$ 2. Lima.

[13] Cussiánovich, A. (1995) “Comentarios a la ponencia El debate actual sobre trabajo Infantil” del doctor Emilio García Méndez. En apuntes $\mathrm{N}^{\circ} 5$ Lima.

[14] Cussiánovich, A. (2010) Una mirada otra sobre trabajo infantil: Imperativo ético y exigencia política. En Revista Internacional desde los Niños/as y Adolescentes Trabajadores. Lima Perú.

[15] Schibotto, G. (2010) El informe global OIT 2010: El triunfo de la razón metonímica. En Revista Internacional desde los Niños/as y Adolescentes Trabajadores. Lima Perú.

[16] Alarcón, W. (1999) Infancia y ciudadanía. En: Realidad y Utopía N² 4, Lima.

[17] Alarcón, W. (1997) Trabajar y Estudiar en los Andes. Aproximación al trabajo infantil en comunidades rurales de Cuzco y Cajamarca. UNICEF, Lima. 
[18] Salazar, C. (1999) Trabajo Infantil y educación en América Latina: Algunos avances y efectos de las políticas educativas en la década de 1990. en Nuevas Perspectivas para Erradicar el Trabajo Infantil en América latina (García Méndez E-Salazar M.C. comps.) TM Editores/UNICEF, Bogotá.

[19] Levison, D. (1991) Are Work and School Incompatible? The Labor Market Activity of Brazilian Children (mss). Yale University, New Haven.

[20] Ruggeri, L., et al. (2003) Does It Matter We Don't Agree on the Definition of Poverty? A Comparison of Four Approaches. Working Paper Number 107, Queen Elizabeth House, University of Oxford, Oxford.

[21] D’angelo, G. (1997) Trabajo Infantil: Abolición o erradicación progresiva? Nuevos términos de una vieja discusión, en Pininos Revista Centroamericana de Análisis y opinión sobre la Niñez $\mathrm{N}^{\circ}$ 9-10 Tegucigalpa.

[22] Alarcón, W. (2000) Profundizando la exclusión. El trabajo de niños y adolescentes en América Latina. Oxfam-Infancia y Desarrollo, Lima.

[23] CEPAL (1995) Panorama Social de América latina 1995. Santiago de Chile.

[24] Parodi, C. (1997) Economía de las políticas sociales. Edic. U. Pacífico lima-Perú.

[25] García, E. (1998) Infancia, Ley y democracia en América Latina. Ed. Temis/depalma Bogotá, Buenos Aires.

[26] Schultz, T. (1961) Investment in Human Capital. The American Economic Review, 51, 1-17. http://www.nber.org/chapters/c3733.pdf

[27] Amaya, A. (1997) Trabajo infantil: Un asunto de ética y derechos humanos. Ponencia presentada el Primer Foro Nacional sobre Trabajo Infantil en Nicaragua. Managua.

[28] Figueroa, C. (2000) Monitoreo de programas sociales: Elementos para la construcción de un índice de bienestar en Vásquez Enrique (editor) impacto de la inversión social en el Perú Lima CIUP-IDRC.

[29] INEI (2016) Magnitud y características del trabajo infantil en Perú: Informe de 2015-Lima Perú.

[30] OIT-IPEC (1998) Trabajo Infantil en los Países Andinos: Bolivia, Colombia, Ecuador, Perú y Venezuela, Atenea Impresores. Lima.

[31] OIT (1996) El Trabajo Infantil. Lo intolerable en el punto de mira. Ginebra.

[32] Alarcón, W. (1996) Trabajo prematuro, educación y ciudadanía en el Perú. en Sociedades y Políticas $\mathrm{N}^{\circ} 2$ Buenos aires.

[33] OIT-IPEC (1997) El Trabajo Infantil en América latina Propuestas para la acción. Lima. 